Link article (Style APA): Kokorina Yu. Ye. \& Psatii A. V. (2021). Eating behavior as a form of self-attitude. Insight: the psychological dimensions of society, 5, 11-29. DOI: 10.32999/2663-970X/2021-5-2

Link article (Style DSTU 8302: 2015): Kokorina Yu. Ye., Psatii A. V. Eating behavior as a form of selfattitude. Insight: the psychological dimensions of society, 2021, 5, 11-29. D0I: 10.32999/2663-970X/2021-5-2

UDC 159.923:642-056.25

\title{
Eating behavior as a form of self-attitude
}

\section{Харчова поведінка як форма самоставлення}

Received: March 10, 2021

Kokorina Yuliia Yevhenivna

Candidate of Psychological Sciences, Associate Professor,

Assistant Professor of the Department of General and Developmental Psychology Odessa I. I. Mechnikov National University, Ukraine ukla75@gmail.com, ORCID 0000-0003-3595-0391

Psatii Alla Volodymyrivna Master of Psychology Odessa I. I. Mechnikov National University, Ukraine prlvrn016@gmail.com, ORCID 0000-0002-6645-3200

\section{Abstract}

The article focuses on the study of personality self-attitudes and the type of eating behavior. The correlation, comparison and qualitative analysis are an attempt to understand the relationship between the type of eating behavior and attitude of the individual to himself. The obtained results help a better understanding and differentiation of a person's formation, expressed through self-attitudes and its derivatives, which form the self-concept of personality, which, in turn, makes it possible to further introduce this experience into psychocorrectional assistance to a person, in particular: to draw up a program for correcting a person's self-attitude, which, in turn, will help balance his eating behavior. The purpose is to study the type of eating behavior and its relationship with a person's attitude to himself. Research methods: During the study, the following methods were applied:
Accepted: May 25, 2021

\section{Кокоріна Юлія Євгенівна}

кандидат психологічних наук, доцент, доцент кафедри загальної психології та психології розвитку особистості Одеський національний університет імені I. I. Мечникова, Україна ukla75@gmail.com,

ORCID 0000-0003-3595-0391

\section{Псатій Алла Володимірівна}

магістрант кафедри загальної психології

та психології розвитку особистості

Одеський національний університет

імені I. I. Мечникова, Україна prlvrn016@gmail.com,

ORCID 0000-0002-6645-3200

\section{Анотація}

Стаття фокусується на вивченні самоставлення особистості та типу харчової поведінки. За допомогою кореляційного, порівняльного та якісного аналізу здійснюється спроба зрозуміти тип харчової поведінки з формою ставлення особистості до себе. Отримані результати допомагають кращому розумінню і диференціації становлення людини, що виражається через самоставлення і його деривати, які формують Я-концепцію особистості. Дозволяє у подальшому впровадити цей досвід у психокорекційну допомогу людині, зокрема: скласти програму корекції самоставлення особистості, що, у свою чергу, допоможе збалансувати їі харчову поведінку. Метою $є$ вивчення типу харчової поведінки та співвідношення його зі ставленням людини до себе. У ході дослідження були застосовані наступні методи: кореляційний, порівняльний та якісний аналіз, тести зі стандартизованими 
correlation, comparative and qualitative analysis, tests with standardized questionnaires. Results: With the help of comparative and qualitative analysis, three types of eating behavior were analyzed and compared with the characteristics of self-esteem, and it was found that the key scales by which groups are differentiated are: integral scale S "self-relation" ( $\mathrm{p} \leq .029)$ and scale "self-acceptance" ( $\mathrm{p} \leq$.039). In a comparative analysis of the data obtained from the experimental and control groups, it was found that the eating behavior for the respondents of the experimental group (with eating disorders) is characterized by high tension in two types: emotional and external types of eating behavior. Conclusions. The study of the "self-relation" factor, which is a structural component of the "Self", also reveals differences between the two groups. It is concluded that eating disorders are closely related to the balance of structural components of the self, such as: self-esteem, self-acceptance, self-interest, which, in turn, affect the psycho-emotional state of a person.

Key words: emotional type of eating behavior, external type of eating behavior, restrictive type of eating behavior, self-relation, features of selfrelation, experimental group, control group.

\section{Introduction}

The problem of the eating disorders in psychology is becoming increasingly widespread. Every year in Ukraine, the number of people with different varieties of abnormalities of eating disorder increases slowly but steadily. The requests for different kinds of help are rising, such as medical-psychiatric, psychological, rehabilitative, etc. There are many reasons associated with an increase in the eating disorders: socio - cultural formation of a socially acceptable way of life for the individual, an image which, in turn, has a psycho-emotional impact on the personality, setting a certain frame of constitution of the subject; personal, associated with a high level of anxiety.

Many researchers have devoted their works to the study the eating behaviour problems, its disorders, and abnormalities, in terms of psychodiagnostic problems, as a phenomenon of body image of the individual and collective subject, noting the sociocultural and psychological aspect of this phenomenon. The contemporary анкетами. За допомогою порівняльного та якісного аналізу було проаналізовано три типи харчової поведінки та порівняно з особливостями самоставлення особистості. Встановлено, що ключовими шкалами, за якими диференціюються групи, $\epsilon:$ шкала S "глобальне самоставлення" (p $\leq .029)$ та шкала "самоприйняття" (p $\leq .039)$. При порівняльному аналізі отриманих даних експериментальної та контрольної груп було встановлено, що харчова поведінка для респондентів експериментальної групи (із порушенням харчової поведінки) відрізняється більшою напругою по двох типах: емоційному та екстернальному типам харчової поведінки. Дослідження фактору “самоставлення”, який $\epsilon$ структурним компонентом “Я”,також виявляє відмінності між двома групами. Зроблено висновок, що порушення харчової поведінки тісно пов'язано зі збалансованістю структурних компонентів Я, таких як: самоставлення, самоприйняття, самоінтерес, які, в свою чергу, впливають на психоемоційний стан людини. Отримані результати дослідження доцільно операціоналізувати в психокорекційних і психопрофілактичних програмах в рамках роботи з порушенням харчової поведінки особистості.

Ключові слова: емоційний тип харчової поведінки, екстернальний тип харчової поведінки, обмежувальний тип харчової поведінки, самоставлення, особливості самоставлення, експериментальна група, контрольна група.

\section{Вступ}

Проблема порушень харчової поведінки у психології стає все більш поширенішою. 3 кожним роком в Україні повільно, але неухильно зростає кількість людей із різноманітними варіантами патологї харчової поведінки. Зростає також кількість звернень за різного роду допомогою: медико-психіатричною, психологічною, реабілітаційною тощо. Причин, пов'язаних зі зростанням порушень харчової поведінки, безліч: соціально-культуральні - формування соціально прийнятного способу життя людини, її образу, який, в свою чергу, здійснює психоемоційний вплив на особистість, задаючи певну рамку конституювання суб'єкта; особистісний, пов'язаний з високим рівнем тривоги.

Вивченню проблем харчової поведінки, її розладів та порушень присвятили свої роботи багато дослідників, акцентуючи увагу на психологічних особливостях розладів 3 точки зору проблем психодіагностики, як феномену тілесності індивідуального та колективного

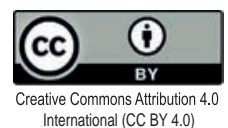


view of scientists on eating disorders is based on the understanding it as a maladaptive way of resolving conflicts (Moizrist, 2009; Malkina-Pykh, 2007), as a connection of eating stereotype with own body image and its activities, related to selfconcept (Kovalchuk, 2019), as a disturbance in body image (Bruch, 1974), as a manifestation of a certain cognitive rigidity (Tchanturia, Lloyd, 2013).

However, despite the rich experience in studying eating disorders, the problem of the relationship between the type of eating behaviour and a person's self-esteem has not been studied. Therefore, it becomes a conceptual framework for the present study.

Hypothesis. The authors admit that eating behaviour type is a form of self-expression, a form of attitude to oneself, creating a unified framework/ vector of people's constitution: the more well-formed and stable the attitude to oneself, the more balanced the eating behaviour is.

Purpose is to study the type of an eating behaviour und correlate to people's self-attitude.

The tasks are:

1. Empirically investigate the types of the eating behaviour.

2. To study specific features of the selfattitude.

3. To perform a qualitative and comparative analysis of the obtained data in the group with disturbed food behaviour and in the group with balanced food behaviour.

\section{Methodology}

It is known that attitudes towards oneself can be demonstrated in various ways: via the valuemental sphere system, which manifests itself also in human behaviour, particularly in food behaviour. Food often takes on the form of a metaphor for relationships and communication and is aimed not only at satisfying biological and physiological, but also psychological and social needs. In other words, eating behaviour is an integral part of a person's functioning, and it is the key line that reveals the way people view themselves. This view correlates with scientific views of the systemstructural approach (Anayev B. G., Leontiev O. M., Rubinstein S. L., and others), psychodynamic approach (Klein M., Lacan J., Freud Z., and others), allowing us to analyse a person in all his/her суб'єкту, відзначаючи соціокультурний та психологічний аспект цього феномену. Сучасний погляд науковців на порушення харчової поведінки виходить із розуміння їі як дезадаптивного способу вирішення конфліктів (Мойзріст, 2009; Малкіна-Пих, 2007), як зв'язку стереотипу харчування з образом власного тіла та діяльності, які пов'язані з Я-концепцією (Ковальчук, 2019); як порушення образу власного тіла (Bruch, 1974); як прояву певної когнітивної ригідності (Tchanturia, Lloyd, 2013).

Але, незважаючи на те, що накопичено багатий досвід із вивчення порушень харчової поведінки, проблема співвідношення та взаємозв'язку між типом харчової поведінки та ставленням особистості до себе, не була вивчена. Тому це стає концептуальною рамкою даного дослідження.

Гіпотеза. Автори припускають, що тип харчової поведінки $\epsilon$ формою висловлювання себе, формою ставлення до себе, створюючи єдину рамку/вектор конституювання людини: чим більш сформоване і стабільне ставлення до себе, тим більше збалансована харчова поведінка.

Мета даної роботи - вивчити тип харчової поведінки та співвіднести його зі ставленням людини до себе.

Завдання:

Емпірично дослідити типи харчової поведінки.

Вивчити особливості самоставлення особистості.

Здійснити якісний та порівняльний аналіз отриманих даних у групі з порушенням харчової поведінки та в групі зі збалансованою харчовою поведінкою.

\section{Методологія}

Відомо, що ставлення до себе може демонструватися різними способами: через систему ціннісно-смислової сфери, яка проявляється в тому числі і в поведінці людини, зокрема в харчовій поведінці. Досить часто їжа набуває характеру метафори відносин та комунікації, і спрямована не тільки на задоволення біологічних та фізіологічних, але й психологічних та соціальних потреб. Інакше кажучи, 
totality of manifestations: from behaviour, as a certain kind of activity, to the system of views on oneself.

Participants. The research was carried out in the medical centre "Revocanda plus" (Kyiv) to study the types of eating behaviour and specific features of person's self-esteem. The research involved 70 respondents who, in turn, were divided into two groups: Experimental (35 individuals who sought treatment in terms of eating disorders) and control (35 individuals without diagnosed signs of eating disorders), aged 16 to 50 years.

Procedure and tools. During the research, a diagnostic toolkit was used to investigate and obtain a qualitative and quantitative assessment of eating disorders and the level of self-esteem of the participants. The Dutch Eating Behaviour Questionnaire (1986) allows three types of eating behaviour to be examined: emotional type of eating behaviour, external type of eating behaviour, restrictive type of eating behaviour. Normal values for restrictive, emotional, and external types of eating behaviours for people with normal weight are $2.4,1.8$ and 2.7 , respectively.

V.V.Stolin's Self-Esteem Questionnaireincludes the following scales: $\mathrm{S}$ - global self-esteem, scale I - self-esteem; scale II - autosympathy, scale III expected attitude from the others; scale IV - selfinterest. The questionnaire also contains seven scales aimed at measuring the of attitudes towards certain inner actions towards the self of respondent: scale 1 - self-esteem; scale 2 the attitude of others; scale 3 - self-acceptance; scale 4 - self-consistency, self-consistency; scale 5 - self-incrimination; scale 6 - self-interest; scale 7 - self-understanding. The interpretation of the obtained data was carried out according to their manifestation, with the values of the 1-3 stheneare conditionally considered low, 4-7 - medium, 8-19 - high (Stolin, Bodalev, 2006).

Statistical analysis. Statistical processing of empirical data and graphical presentation of the results was carried out using SPSS17,0 statistics. The non-parametric Mann-Whitney U-criterion was used to test the statistically significant differences in eating behaviour and self-esteem. харчова поведінка є невід'ємною складовою функціонування особистості, і саме вона стає тою ключовою ланкою, через яку дає про себе знати спосіб бачення людиною себе. Такий погляд співвідноситься 3 науковими поглядами системно-структурного підходу (Анаьєв Б.Г., Леонтьев О.М., Рубінштейн С.Л. та ін.), психодинамічного підходу (Кляйн М., Лакан Ж., Фрейд 3. та ін.), дозволяючи аналізувати людину у всій їі сукупності проявів: від поведінки, як певного виду діяльності, до системи поглядів на себе.

Учасники. 3 метою вивчення типів харчової поведінки та особливостей самоставлення особистості було проведено дослідження на базі медичного центру "Revocanda plus" (м. Київ).У досліджені прийняли участь 70 респондентів, які були поділені на дві групи: експериментальну (35 осіб,які звернулися за допомогою з приводу лікування розладів харчової поведінки) та контрольну (35 осіб, без діагностованих ознак порушення харчової поведінки), віком від 16 до 50 років.

Процедура та інструменти. Впродовж дослідження застосовано діагностичний інструментарій, який дозволяє дослідити і отримати якісну та кількісну оцінку розладів харчової поведінки, та рівень самоставлення досліджуваного до себе. Голландський опитувальник харчової поведінки (Dutch Eating Behavior Questionnaire, 1986) дозволяє вивчити три типи харчової поведінки: емоційний тип харчової поведінки, екстернальний тип харчової поведінки, обмежувальний тип харчової поведінки. Нормальними значеннями обмежувального, емоційного і екстернального типів харчової поведінки для людей з нормальною вагою складають 2.4, 1.8 і 2.7 бала відповідно.

Опитувальник самоставлення Століна В.В. включає в себе наступні шкали: S - глобальне самоставлення, шкала I - самоповага; шкала II - аутосимпатія, шкала III - очікуване ставлення від інших; шкала IV - самоінтерес. Опитувальник містить також сім шкал, спрямованих на вимірювання прояву установки на ті чи інші внутрішні дії на адресу "Я" респондента: шкала 1 - самовпевненість; шкала 2 - ставлення інших; шкала 3 - самоприйняття; шкала 4 - самокерування, самопослідовність; 


\section{Results}

Qualitative and comparative analysis of the type of individual's eating behaviour

Usingthe "DutchFoodBehaviourQuestionnaire" ("DEBQ") method, the types of eating behaviour of the respondents were determined, and it was found that among the experimental group prevails the emotional type of eating behaviour: the average value obtained by interpreting the data is 39.17 , the arithmetic mean is 3.9 , which is significantly higher than the normative value of emotional behaviour for people with normal weight $(2,4)$

The corresponding value for the external type of eating behaviour is 26.57 (arithmetic mean is 2.04), which is also higher than the normative value for the external type of eating behaviour (1.8), and the similar value for the restrictive type of eating behaviour is 29.80 (arithmetic mean is 2.9), which is only slightly higher than the normative value (2.7).

With qualitative analysis, it may be seen that the structure of responses among the respondents in the experimental group, on scales responsible for the emotional type of eating behaviour, is more monotonous in nature with a single peak in the range of 36-39 points (Fig. 1).

This dynamic may indicate the influence of vivid/strong emotions on the person, such as: anger, fear, anxiety, which significantly affect their behaviour, particularly eating behaviour. In other words, it could be spoken about a shifting strategy, where food becomes the object on which the semantic focus shifts.

At the same time, a similar structure of responses that indicate an external type of eating behaviour is wider, with peaks all around the responses (Fig. 2).

These dynamics may demonstrate a response strategy to external stimuli that is varied: the sight of the person eating, the smell of the food, the sight of eatable foods and products from billboards, etc., that is, such people "eat" food with their eyes. It should be noted that food, for respondents with this type of eating behaviour, can become a mean of communication and encouragement, as food becomes a link in interpersonal communication. The characteristic of the restrictive type of eating behaviour is mingled (Fig. 3.). Such dynamics can demonstrate respondents' attempts to control шкала 5 - самозвинувачення; шкала 6 - самоінтерес; шкала 7 - саморозуміння. Інтерпретація отриманих даних здійснювалася в залежності від їх прояву, при цьому значення 1-3 стену умовно вважаються низькими, 4-7 - середніми, 8-19 - високими (Столін, Бодалев, 2006).

Статистичне аналізування. Статистичну обробку емпіричних даних і графічну презентацію результатів здійснено за допомогою пакету статистичних програм SPSSv.17.0. Для перевірки статистичної значущості відмінностей особливостей харчової поведінки та самоставлення використовувався непараметричний U-критерій Манна-Уітні.

\section{Результати \\ Якісний та порівняльний аналіз типу харчової поведінки особистості}

За допомогою методики "Голландський опитувальник харчової поведінки” (“DEBQ”) було визначено типи харчової поведінки респондентів та виявлено, що серед досліджуваних експериментальної групи переважає емоційний тип харчової поведінки: середнє значення, отримане при інтерпретації даних, становить 39.17, тобто середнє арифметичне складає 3.9, що суттєво вище нормативних показників емоціогенної поведінки для людей 3 нормальною вагою (2.4).

Відповідне значення за типом екстернальної харчової поведінки становить 26.57 (середнє арифметичне складає 2.04), що також вище нормативного показника для екстернального типу харчової поведінки (1.8), а аналогічний показник обмежувального типу харчової поведінки становить 29.80 (середнє арифметичне складає 2.9), що лише несуттєво вище нормативного показника (2.7).

При якісному аналізі можна побачити, що структура відповідей у респондентів експериментальної групи за шкалами, які відповідають за емоційний тип харчової поведінки, носить більш одноманітний характер $з$ одиночним піком у проміжку 36-39 балів (рис. 1).

Така динаміка може свідчити про вплив яскравих/сильних емоцій на людину, таких як: гнів, страх, тривога, які суттєво впливають на її поведінку, зокрема харчову. Інакше кажучи, можна говорити про стратегію зсуву, через 
themselves, their emotional state, i.e., to be more self-controlled, which manifests itself through this type of eating behaviour.

When examining eating behaviour in the control group, it was found that the respondents in this group were also characterised by an emotional type of eating behaviour. The mean value obtained on the scale of the emotional type of eating behaviour is 17.91 , i.e., the arithmetic mean value is 1.8 , which is lower than the normative values of the emotional behaviour of people with normal weight (2.4).

The relevant value for the external type of eating behaviour is 17.83 (arithmetic mean яку особистість шукає спосіб впоратися з негативними переживаннями, де їжа стає тим об'єктом, на який переноситиметься смисловий акцент.

У той же час, аналогічна структура відповідей, що позначають екстернальний тип харчової поведінки, носить більш різноманітний характер з піками по всьому периметру відповідей (рис. 2).

Така динаміка може демонструвати стратегію реагування на зовнішні стимули, яка має різноманітний характер: вигляд людини, що приймає їжу, запах їжі, харчові продукти, вигляд їстівних страв та продуктів з рекламних

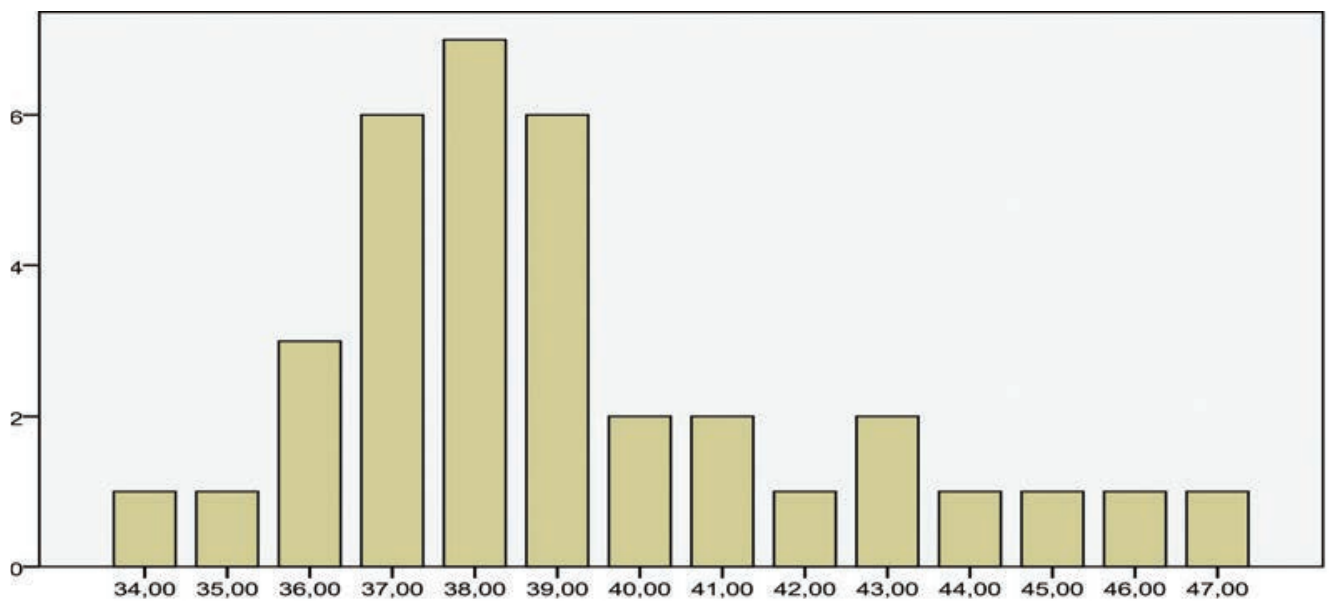

Fig. 1. Peculiarities of the manifestation of emotional type of eating behaviour in the experimental group.

Рис. 1. Особливості прояву емоційного типу харчової поведінки в експериментальній групі

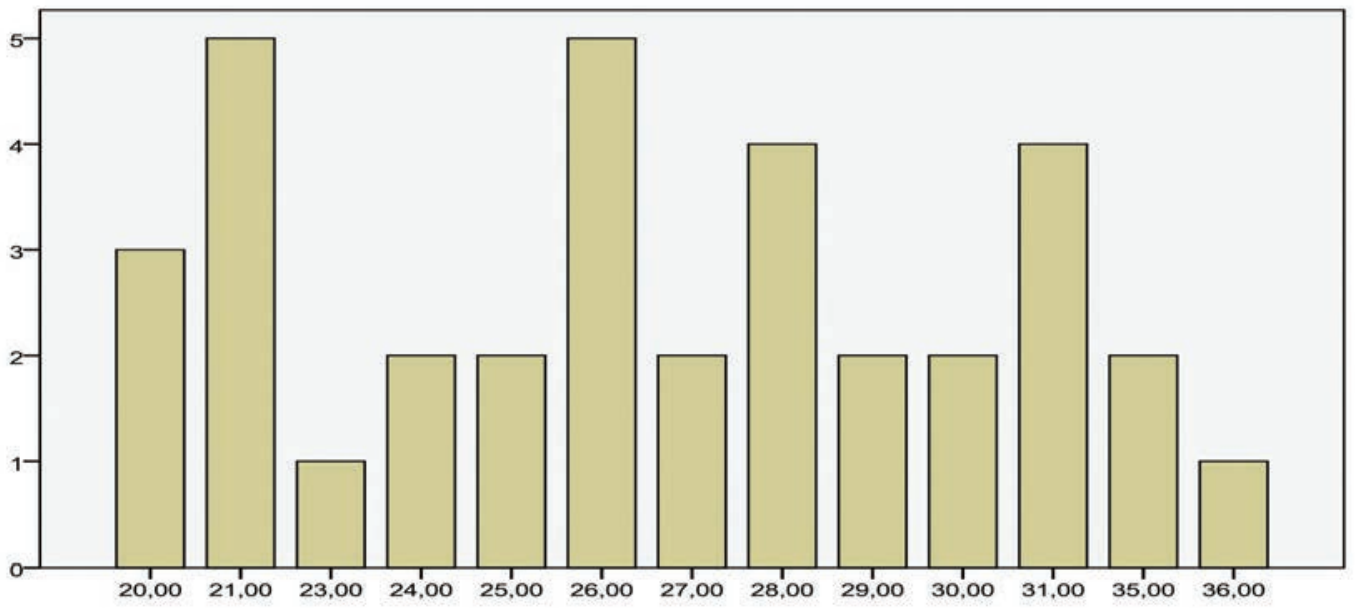

Fig. 2. Peculiarities of the external type of eating behaviour in the experimental group

Рис. 2. Особливості прояву екстернального типу харчової поведінки в експериментальній групі 
is 1.4), which is also lower than the normative values for external type of eating behaviour (1.8).

The value for restrictive type of eating behaviour is 15.66 (arithmetic mean is 1.6), which is also lower than the normative value (2.7).

The structure of the respondents' answers on the scales responsible for the emotional type of eating behaviour is more stable with two spikes of 25 and 37 points (Fig. 4). щитів тощо, тобто такі люди “їдять” їжу очими. Слід зазначити, що вживання їжі для респондентів, якім притаманний даний тип харчової поведінки, може ставати засобом комунікації і заохочення, оскільки їжа стає сполучною ланкою у міжособистісній комунікації.

Характеристика обмежувального типу харчової поведінки носить змішаний характер (рис. 3). Така динаміка може демонструвати

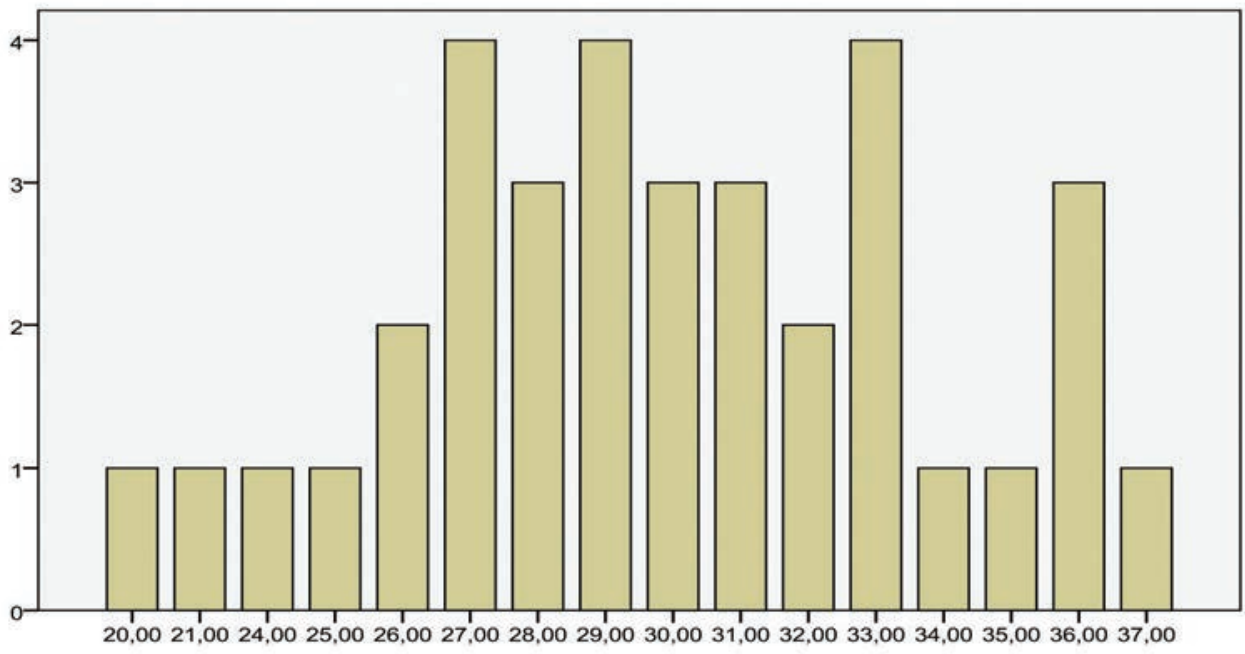

Fig. 3. Peculiarities of restrictive type of eating behaviour (experimental group)

Рис. 3. Особливості прояву обмежувального типу харчової поведінки (експериментальна група)

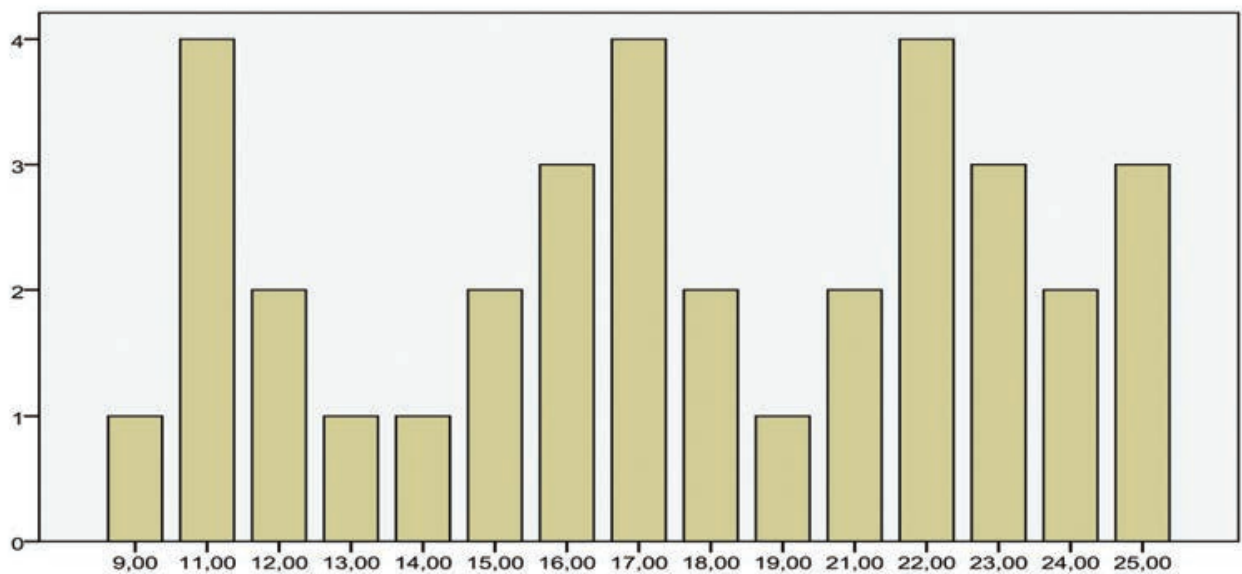

Fig. 4. Peculiarities of the expression of the emotional type of eating behaviour in the control group

Рис. 4. Особливості прояву емоційного типу харчової поведінки в контрольній групі 


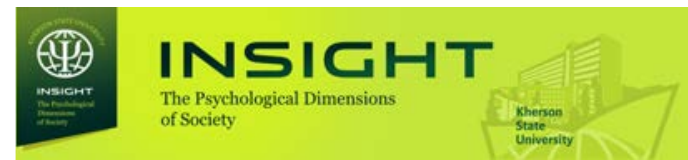

The corresponding pattern of the responses of the external type of behaviour does not differ from the previous one in terms of relative stability (Figure 5). Such dynamics may indicate that respondents in the control group are not inclined to respond to external stimuli via changes in eating behaviour.

The structure of responses which are responsible for a restrictive type of eating behaviour is presented in Fig. 6. It can be noted that a balanced control over what and how much they eat is typical for respondents of this group.

Therefore, interpreting the obtained data, it is possible to speak about influence on the person

\section{Kokorina Yuliia, \\ Psatii Alla}

спроби респондентів проконтролювати себе, свій емоційний стан, тобто бути більш вимогливими до себе, що проявляється через даний тип харчової поведінки.

При вивченні особливостей харчової поведінки у контрольній групі було встановлено, що для респондентів цієї групи також притаманний емоційний тип харчової поведінки. Середнє значення, отримане за шкалою емоційного типу харчової поведінки, становить 17.91, тобто середнє арифметичне складає 1.8, що нижче нормативних показників емоціогенної поведінки для людей з нормальною вагою $(2,4)$.

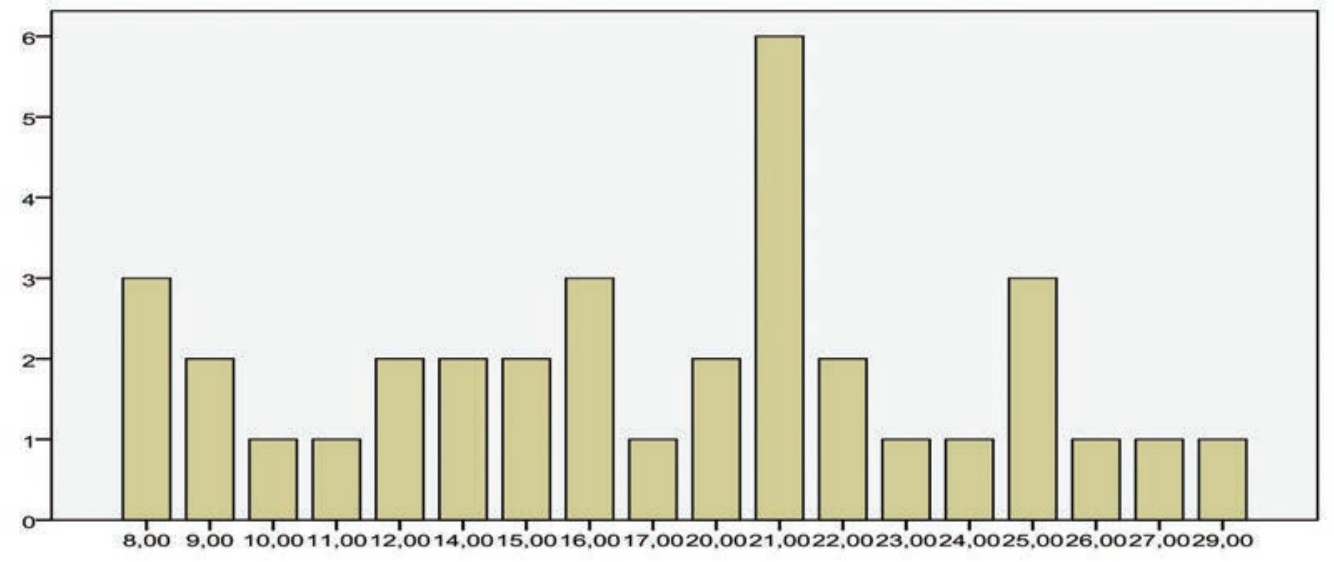

Fig. 5: Peculiarities of external type of eating behaviour in the control group

Рис. 5. Особливості прояву екстернального типу харчової поведінки у контрольній групі

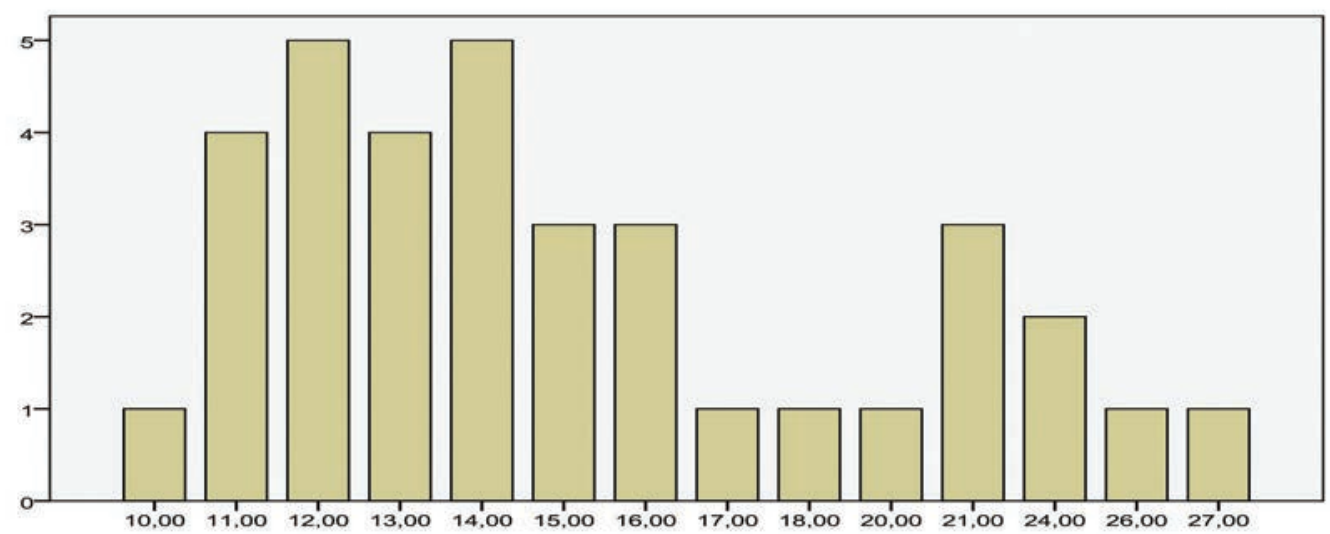

Fig. 6. Peculiarities of the manifestation of a restrictive type of eating behaviour (control group) Рис. 6. Особливості прояву обмежувального типу харчової поведінки (контрольна група) 
of a set of factors of external environment which, in turn, reflect a mental condition/personal and semantic characteristic of the person, correlates with views of scientists of systemstructural approach (Ananyev B. G., Leontiev V. N., Platonov K. K., Rubinstein S. L., etc.). From the perspective of psychoanalytic discourse, eating disorders appear only as a means, whereas the goal is a certain desire: to be the object of another's desire. Hunger is not an expression of the body's increased need for food, because it becomes an object that replaces pleasure with frustrated emotional needs that have nothing to do with the eating process. Strong craving for love and aggressive tendencies for incorporation form an unconscious basis for abnormal appetite disorder (Lacan J., Freud Z.).

It should be noted that in the comparative analysis of the data obtained by the experimental and control groups, the eating behaviour of the respondents in the experimental group differs by more tension in the two types of eating behaviour than for the respondents in the control group.

The statistical significance of the differences in eating behaviour patterns was tested and the nonparametric Mann-Whitney test was used for this purpose.
Відповідне значення за типом екстернальної харчової поведінки становить 17.83 (середнє арифметичне складає 1.4), що також нижче нормативного показника для екстернального типу харчової поведінки (1.8).

Показник обмежувального типу харчової поведінки становить 15.66 (середнє арифметичне складає 1.6), що також нижче нормативного показника (2.7).

Структура відповідей досліджуваних за шкалами, які відповідають за емоційний тип харчової поведінки, носить більш стабільний характер з двома піками у 25 та 37 балів (рис. 4).

Відповідна структура відповідей екстернального типу поведінки не відрізняється від попередньої відносною стабільністю (рис.5). Така динаміка може свідчити про те, що респонденти контрольної групи не схильні реагувати на зовнішні подразники зміною у харчовій поведінці.

Структура відповідей, що відповідають за обмежувальний тип харчової поведінки (рис. 6). Тобто, можна відмітити, що для респондентів даної групи характерна збалансованість контролю за тим, що і в якій кількості вони їдять.

Table 1: Differences in the mean ranks in the experimental and control groups

Таблиця 1. Відмінності середніх рангів в експериментальній та контрольній групах

\begin{tabular}{|c|c|c|c|c|}
\hline & $\begin{array}{l}\text { Group } \\
\text { Група }\end{array}$ & $\mathbf{N}$ & $\begin{array}{c}\text { Mean ranks } \\
\text { Середній ранг }\end{array}$ & $\begin{array}{l}\text { Sum of ranks } \\
\text { Сума рангів }\end{array}$ \\
\hline \multirow{3}{*}{$\begin{array}{l}\text { Emotional type of eating behaviour } \\
\text { Емоційний тип харчової поведінки }\end{array}$} & $\begin{array}{c}\text { Experimental } \\
\text { Експериментальна }\end{array}$ & 35 & 53.00 & 1855.00 \\
\hline & $\begin{array}{c}\text { Control } \\
\text { Контрольна }\end{array}$ & 35 & 18.00 & 630.00 \\
\hline & $\begin{array}{c}\text { Total } \\
\text { Всього }\end{array}$ & 70 & & \\
\hline \multirow{3}{*}{$\begin{array}{c}\text { External type of eating behaviour } \\
\text { Екстернальний тип харчової поведінки }\end{array}$} & $\begin{array}{c}\text { Experimental } \\
\text { Експериментальна }\end{array}$ & 35 & 48.26 & 1689.00 \\
\hline & $\begin{array}{c}\text { Control } \\
\text { Контрольна }\end{array}$ & 35 & 22.74 & 796.00 \\
\hline & $\begin{array}{c}\text { Total } \\
\text { Всього }\end{array}$ & 70 & & \\
\hline \multirow{3}{*}{$\begin{array}{l}\text { Restricted type of eating behaviour } \\
\text { Обмежувальний тип харчової поведінки }\end{array}$} & Experimental & 35 & 52.34 & 1832.00 \\
\hline & $\begin{array}{c}\text { Control } \\
\text { Контрольна }\end{array}$ & 35 & 18.66 & 653.00 \\
\hline & $\begin{array}{c}\text { Total } \\
\text { Всього }\end{array}$ & 70 & & \\
\hline
\end{tabular}




In the table below (Table 1.) the mean ranks and their sums in the experimental and control groups have different values.

The next task was to analyse the statistical significance of these differences. The results are shown in table 2 .

Thus, as it can be seen from the table above, the experimental and control groups differ from each other in all types of eating behaviour: restrictive, emotional, and external with a high level of statistical significance $(p \leq 0.001)$.

Studying the characteristics of self-esteem in the experimental and control groups

The V. V. Stolin and S. G. Panteleev questionnaire was used; the peculiarities of a personality's self-esteem were studied.

Interpretation of the received data was carried out depending on their manifestation.

The results of the study of self-esteem features in the experimental group are shown in Table 3.

As it can be seen from this table, no expressed scores were obtained in the subject group - none of them exceeds the critical value (74).

However, the most significant values are observed on the following scales: S scale (global self-concept), self-interest scale, self-consistency scale and self-interest scale.

A similar analysis of the obtained results of the study of self-esteem features in the control group showed similar results (Table 4.).

The highest values were obtained on the scale of "self-interests" (65.52), as well as on the scales: "self-consistency" (54.33), "self-interest" (57.47) and "self-incrimination" (59.32), which refer
Отже, інтерпретуючи отримані дані, можна говорити про вплив на людину сукупності факторів зовнішнього середовища, які, в свою чергу, відбивають психічний стан/особистісносмислові характеристики людини, що корелює 3 поглядами науковців системно-структурного підходу (Б. Г. Ананьєв, О. М. Леонтьєв, К. К. Платонов, С. Л. Рубінштейн та ін.). 3 точки зору психоаналітичного дискурсу, порушення харчової поведінки виглядає лише як засіб, водночас як метою є певне бажання: бути об'єктом бажання іншого. Голод не є вираженням збільшеної потреби організму в їжі, бо вона стає тим об'єктом, який заміщує задоволення фрустрованих емоційних потреб, що не мають нічого спільного з процесом харчування. Сильна спрага любові, агресивні тенденції до інкорпорації формують несвідому основу для патологічного порушення апетиту (Ж.Лакан, З.Фрейд).

Слід зазначити, що при порівняльному аналізі отриманих даних експериментальної і контрольної груп харчова поведінка для респондентів експериментальної групи відрізняється більшою напругою за двома типами харчової поведінки, ніж для респондентів контрольної групи.

Далі було перевірено статистичну значущість відмінностей особливостей харчової поведінки, з цією метою використано непараметричний критерій Манна-Уітні.

В наведеній нижче таблиці (табл. 1.) можна побачити, що середні ранги та їхні суми в експериментальній і контрольній групах мають різні значення.

Table 2. Statistical significance of eating behaviour in the experimental and control groups

Таблиця 2. Статистична значущість особливостей харчової поведінки в експериментальній та контрольній групах

\begin{tabular}{|c|c|c|c|}
\hline & $\begin{array}{c}\text { Emotional } \\
\text { Емоційний }\end{array}$ & $\begin{array}{c}\text { External } \\
\text { Екстернальний }\end{array}$ & $\begin{array}{c}\text { Restrictive } \\
\text { обмежувальний }\end{array}$ \\
\hline $\begin{array}{l}\text { Statistic U by Mann- Whitney } \\
\text { Статистика U Манна-Уітні }\end{array}$ & .000 & 166.000 & 23.000 \\
\hline $\begin{array}{c}\text { Statistic W by Wilcoxon } \\
\text { Статистика W Вілкоксона }\end{array}$ & 630.000 & 796.000 & 653.000 \\
\hline $\mathrm{Z}$ & -7.206 & -5.260 & -6.933 \\
\hline $\begin{array}{l}\text { Asymptotic value (two-sided) } \\
\text { Асимпт. знч. (двостороння) }\end{array}$ & .000 & .000 & .000 \\
\hline \multicolumn{4}{|c|}{$\begin{array}{c}\text { a. Group variables: group } \\
\text { а. Групувальна змінна: група }\end{array}$} \\
\hline
\end{tabular}


to the structural components/self-attitudes addresses to "self" (self-concept). As well as a decrease in the values on the $\mathrm{S}$ scale (global selfesteem) of 54.94can be seen.

Despite the similarity of the results, the statistical significance of the differences between the results of the study of self-esteem in the control and experimental groups was also tested using the non-parametric Mann-Whitney criterion (Table 5.).

According to the table above, the mean ranks and their sums have different values in the experimental and control groups.

After that the statistical significance of these differences was analysed (Table 6.).
Наступним завданням було аналізування статистичної значущості цих відмінностей. Отримані данні зображено у таблиці 2.

Таким чином, як можна побачити у вищенаведеній таблиці, експериментальна та контрольна група відрізняються між собою усіма типами харчової поведінки: обмежувальним, емоційним та екстернальним із високим рівнем статистичної значущості ( $\mathrm{p} \leq .001)$.

Вивчення особливостей самоставлення в експериментальній та контрольній групах

За допомогою опитувальника В. В. Століна та С. Р. Пантелеєва (ОСО)було вивчено особливості самоставлення особистості.

Table 3. Peculiarities of self-esteem in the research experimental group (mean values)

Таблиця 3. Особливості самоставлення у досліджуваних експериментальної групи (середні значення)

\begin{tabular}{|c|c|c|c|c|c|c|c|c|c|c|c|c|}
\hline & 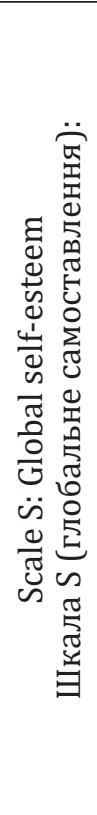 & 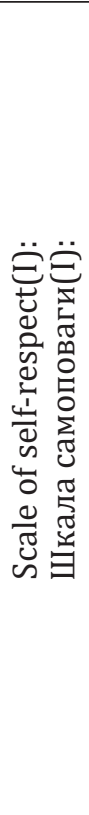 &  &  & 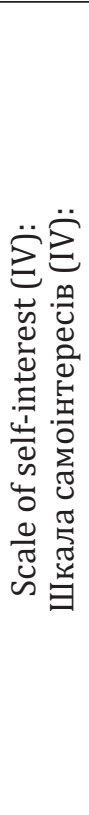 & 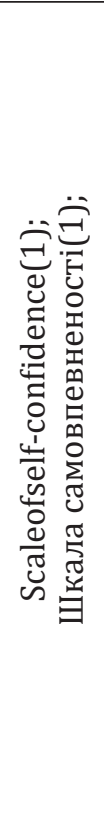 &  & 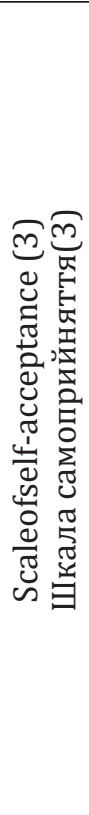 & 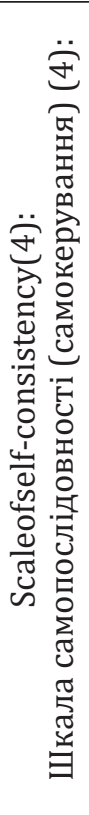 & 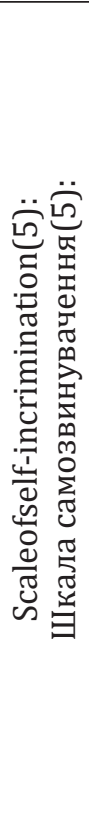 & 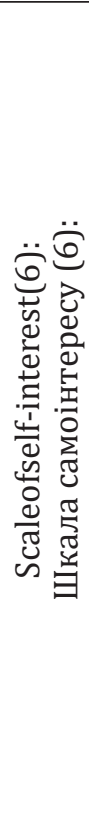 & 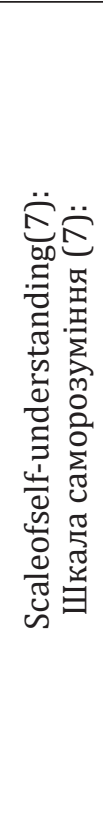 \\
\hline 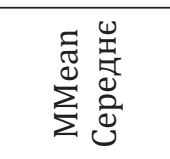 & 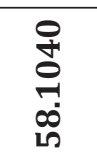 & $\begin{array}{l}\hat{N} \\
\stackrel{7}{0} \\
\text { in }\end{array}$ & \begin{tabular}{l} 
मे \\
2 \\
$\infty$ \\
\multirow{2}{*}{}
\end{tabular} & \begin{tabular}{l} 
mo \\
o \\
\multirow{2}{*}{} \\
m
\end{tabular} & $\begin{array}{l}\text { Na} \\
\text { m} \\
\stackrel{i}{0}\end{array}$ & 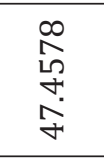 & $\begin{array}{l}0 \\
\stackrel{1}{ } \\
o \\
o \\
\dot{+} \\
m\end{array}$ & $\begin{array}{l}\vec{m} \\
\stackrel{N}{N} \\
\text { ம் }\end{array}$ & $\begin{array}{l}\text { N } \\
\text { Jे } \\
0 \\
\infty \\
10\end{array}$ & 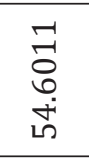 & $\begin{array}{l}9 \\
0 \\
0 \\
0 \\
0\end{array}$ & 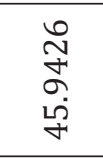 \\
\hline 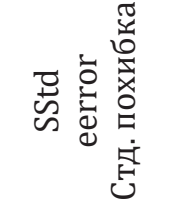 & 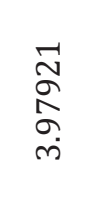 & $\begin{array}{l}\text { के } \\
\text { oू } \\
\text { Oे } \\
\dot{+}\end{array}$ &  &  & $\begin{array}{l}m \\
m \\
\overrightarrow{\tilde{m}} \\
\dot{m} \\
\dot{m}\end{array}$ & $\begin{array}{l}\text { Nิ } \\
\text { Wh } \\
\stackrel{\omega}{0} \\
\text { r. }\end{array}$ &  & 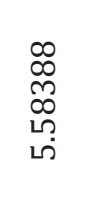 & 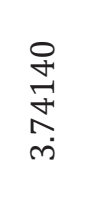 & $\begin{array}{l}8 \\
\stackrel{1}{0} \\
\infty \\
o \\
\stackrel{+}{+}\end{array}$ & 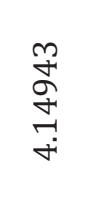 & $\underset{\stackrel{\sim}{*}}{\stackrel{\sim}{+}}$ \\
\hline 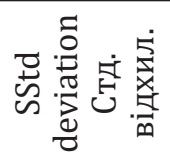 & $\begin{array}{l}\stackrel{m}{m} \\
\stackrel{7}{*} \\
\text { ஸे } \\
\stackrel{n}{N}\end{array}$ & 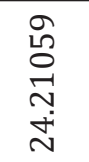 & 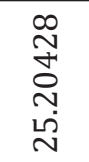 & $\begin{array}{l}\text { Nै } \\
\text { Oे } \\
\infty \\
\text { N } \\
\text { N }\end{array}$ & $\begin{array}{l}\underset{N}{N} \\
\infty \\
\infty \\
\stackrel{\sim}{+}\end{array}$ & 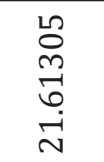 & $\begin{array}{l}\hat{N} \\
\text { Oे } \\
\stackrel{+}{+} \\
\text { ָे }\end{array}$ & 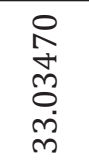 & 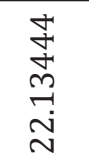 & 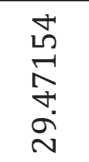 & \begin{tabular}{l} 
ले \\
$\infty$ \\
\multirow{+}{+}{} \\
ஸे \\
N
\end{tabular} & 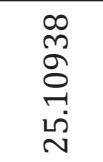 \\
\hline
\end{tabular}

Note: The load of significant variables is highlighted in bold.

Примітка: Навантаження значущих змінних виділено жирним шрифтом. 




As it can be seen from the table below, the experimental and control groups differ from each other on the integral scale $S$ "global selfesteem". The control group has more positive self-esteem characteristics ( $\mathrm{p} \leq$.029) and on scale 3 ("self-acceptance") with statistical significance level $(\mathrm{p} \leq 0.039)$.

\section{Discussion}

The results open the field for further discussion. The methodological basis of this study is the position of system-structural and psychodynamic approaches. The structure of respondents' self-esteem in the two groups, depending on the type of eating behaviour, along with the similarities, has some peculiarities.

Paying attention to the data on the values of the type of eating behaviour of the respondents

\section{Kokorina Yuliia,} Psatii Alla

Інтерпретація отриманих даних здійснювалася в залежності від їх прояву.

Результати дослідження особливостей самоставлення в експериментальній групі наведено у таблиці 3.

Як можна побачити із даної таблиці, яскраво виражених показників у групі досліджуваних не отримано - жоден із них не перевищує критичне значення (74).

Однак, найбільш вагомі показники спостерігаються за наступними шкалами: шкала S (глобальне самоставлення), шкала самоінтересів, шкала самопослідовності та шкала самоінтересу.

Аналогічний аналіз отриманих результатів дослідження особливостей самоставлення у контрольній групі показав схожі результати (табл. 4.).

Як можна побачити із даної таблиці, яскраво виражених показників у групі досліджуваних не отримано - жоден із них не перевищує критичне значення (74).

Table 4. Peculiarities of self-esteem in the control group (average values)

Таблиця 4. Особливості самоставлення у досліджуваних контрольної групи (середні значення)

\begin{tabular}{|c|c|c|c|c|c|c|c|c|c|c|c|c|}
\hline & 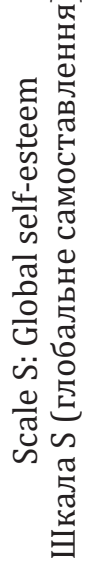 & 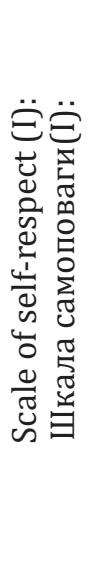 & 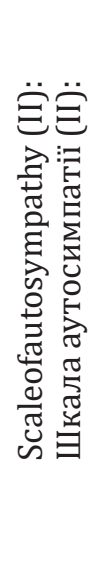 & 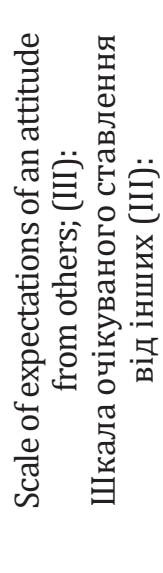 & 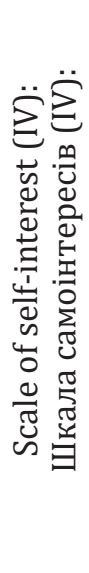 &  & 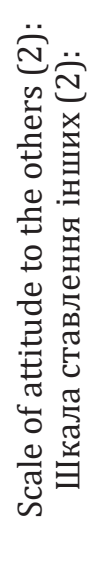 & 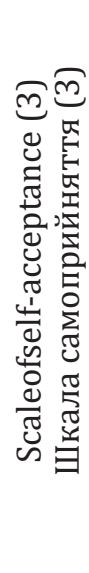 & 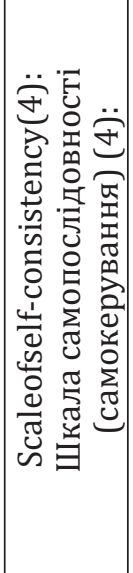 & 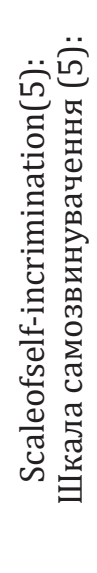 & 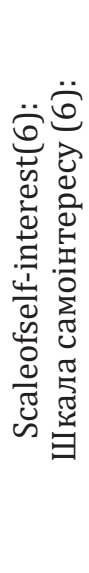 & 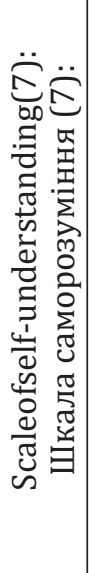 \\
\hline 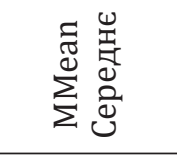 &  & $\begin{array}{l}\hat{2} \\
\text { 오 } \\
\text { \& }\end{array}$ & 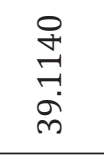 & 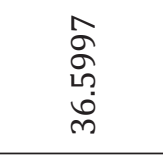 & $\begin{array}{l}\text { กี้ } \\
\text { น้ } \\
\text { กู่ }\end{array}$ & 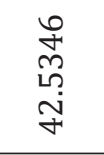 & 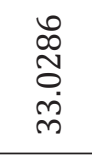 & $\begin{array}{l}m \\
\infty \\
0 \\
0 \\
\dot{m} \\
\dot{m}\end{array}$ & $\begin{array}{l}\text { เึ } \\
\text { ก๊ } \\
\text { เึ่ }\end{array}$ & $\begin{array}{l}\stackrel{g}{+} \\
\text { ñ } \\
\text { ì }\end{array}$ & $\begin{array}{l}8 \\
0 \\
0 \\
\text { ț } \\
\text { 1. }\end{array}$ & $\begin{array}{l}\stackrel{8}{0} \\
\stackrel{0}{ } \\
\stackrel{+}{+}\end{array}$ \\
\hline 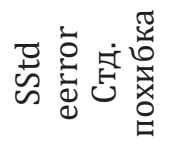 & \begin{tabular}{l}
$\infty$ \\
\multirow{\sigma}{人}{} \\
$\stackrel{\sigma}{v}$
\end{tabular} & $\begin{array}{l}\infty \\
m \\
\sigma \\
i \\
m\end{array}$ & 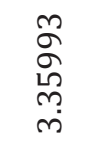 & 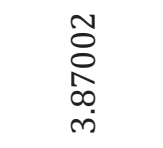 & 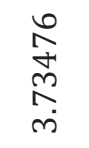 & 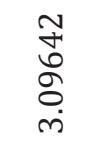 & $\begin{array}{l}\text { Nै } \\
\text { นn } \\
\text { ஸू } \\
\text { mे }\end{array}$ & $\begin{array}{l}\text { ले } \\
\text { ర్ } \\
\text { mे }\end{array}$ & 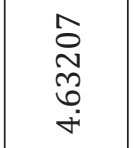 & $\begin{array}{l}0 \\
\stackrel{0}{\infty} \\
m \\
\infty \\
+\end{array}$ &  &  \\
\hline 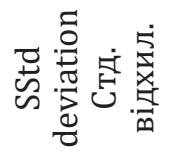 & $\begin{array}{l}10 \\
\infty \\
0 \\
-1 \\
6 \\
\\
-1\end{array}$ &  & $\begin{array}{l}\text { W } \\
\stackrel{1}{1} \\
\infty \\
\sigma \\
\sigma\end{array}$ & $\begin{array}{l}\hat{N} \\
\text { బิ } \\
\infty \\
\text { N } \\
\text { N }\end{array}$ & 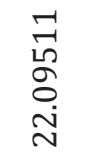 & $\begin{array}{l}a \\
0 \\
\infty \\
\overrightarrow{1} \\
\infty \\
\infty \\
\cdots\end{array}$ & 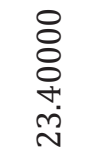 & 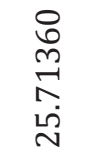 & \begin{tabular}{l}
$\infty$ \\
0 \\
ñ \\
\multirow{+}{+}{} \\
N.
\end{tabular} &  & $\begin{array}{l}\hat{\infty} \\
\stackrel{+}{N} \\
\text { Ñ }\end{array}$ & $\frac{7}{\stackrel{0}{a}}$ \\
\hline
\end{tabular}

Note: The load of significant variables is highlighted in bold.

Примітка: Навантаження значущих змінних виділено жирним шрифтом. 
in the experimental group, we can see the tension on the two types: emotional and externality. Respondents of the control group are characterized by a decrease in all types of eating behaviour.

Therefore, for an individual with an eating disorder, it is possible to see the main strategies
Найвищі значення отримані за шкалою “самоінтереси” (65.52), а також за шкалами: "самокерівництво" (54.33), "самоінтерес" (57.47) та"самозвинувачення" (59.32), які відносяться до структурних компонентів/установок в адрес "Я". А також зниження показників по шкалі S (глобальне самоставлення) - 54.94.

Table 5. Differences in ranks

Таблиця 5. Відмінності рангів

\begin{tabular}{|c|c|c|c|c|}
\hline \multicolumn{5}{|c|}{ Ranks/ Ранги } \\
\hline & $\begin{array}{l}\text { Group } \\
\text { Група }\end{array}$ & $\mathbf{N}$ & $\begin{array}{c}\text { Mean rank } \\
\text { Середній ранг } \\
\end{array}$ & $\begin{array}{l}\text { Sumofranks } \\
\text { Сума рангів }\end{array}$ \\
\hline \multirow{3}{*}{$\begin{array}{l}\text { Scale S (global self-esteem) } \\
\text { Шкала S (глобальне } \\
\text { самоставлення): }\end{array}$} & Experimental/ Експериментальна & 35 & 40.80 & 1428.00 \\
\hline & Control/ Контрольна & 35 & 30.20 & 1057.00 \\
\hline & Total/ Всього & 70 & & \\
\hline \multirow{3}{*}{$\begin{array}{l}\text { Scale of self-esteem (I): } \\
\text { Шкала самоповаги (I): }\end{array}$} & Experimental/ Експериментальна & 35 & 37.90 & 1326.50 \\
\hline & Control/ Контрольна & 35 & 33.10 & 1158.50 \\
\hline & Total/ Всього & 70 & & \\
\hline \multirow{3}{*}{$\begin{array}{l}\text { Scaleofautosympathy (II): } \\
\text { Шкала аутосимпатії (II): }\end{array}$} & Experimental/ Експериментальна & 35 & 38.43 & 1345.00 \\
\hline & Control/ Контрольна & 35 & 32.57 & 1140.00 \\
\hline & Total/ Всього & 70 & & \\
\hline \multirow{3}{*}{$\begin{array}{c}\text { Scale of expected attitude to } \\
\text { others (III): } \\
\text { Шкала очікуваного став- } \\
\text { лення від інших (III): }\end{array}$} & Experimental/ Експериментальна & 35 & 37.34 & 1307.00 \\
\hline & Control/ Контрольна & 35 & 33.66 & 1178.00 \\
\hline & Total/ Всього & 70 & & \\
\hline \multirow{3}{*}{$\begin{array}{l}\text { Scale of self-interest (IV): } \\
\text { Шкала самоінтерсів (IV): }\end{array}$} & Experimental/ Експериментальна & 35 & 35.70 & 1249.50 \\
\hline & Control/ Контрольна & 35 & 35.30 & 1235.50 \\
\hline & Total/ Всього & 70 & & \\
\hline \multirow{3}{*}{$\begin{array}{l}\text { Scaleofself-confidence(1); } \\
\text { Шкала самовпевненості (1); }\end{array}$} & Experimental/ Експериментальна & 35 & 38.04 & 1331.50 \\
\hline & Control/ Контрольна & 35 & 32.96 & 1153.50 \\
\hline & Total/ Всього & 70 & & \\
\hline \multirow{3}{*}{$\begin{array}{l}\text { Scale of attitude to others (2): } \\
\text { Шкала ставлення інших (2): }\end{array}$} & Experimental/ Експериментал & 35 & 35.93 & 1257.50 \\
\hline & Control/ Контрольна & 35 & 35.07 & 1227.50 \\
\hline & Total/ Всього & 70 & & \\
\hline \multirow{3}{*}{$\begin{array}{l}\text { Scaleofself-acceptance (3) } \\
\text { Шкала самоприйняття (3) }\end{array}$} & Experimental/ Експериментальна & 35 & 40.49 & 1417.00 \\
\hline & Control/ Контрольна & 35 & 30.51 & 1068.00 \\
\hline & Total/ Всього & 70 & & \\
\hline \multirow{3}{*}{$\begin{array}{l}\text { Scaleofself-consistency (4): } \\
\text { Шкала самопослідовності } \\
\text { (самокерування) (4): }\end{array}$} & Experimental/ Експериментальна & 35 & 36.81 & 1288.50 \\
\hline & Control/ Контрольна & 35 & 34.19 & 1196.50 \\
\hline & Total/ Всього & 70 & & \\
\hline \multirow{3}{*}{$\begin{array}{l}\text { Scaleofself-incrimination (5): } \\
\text { Шкала самозвинувачення (5): }\end{array}$} & Experimental/ Експериментальна & 35 & 33.79 & 1182.50 \\
\hline & Control/ Контрольна & 35 & 37.21 & 1302.50 \\
\hline & Total/ Всього & 70 & & \\
\hline \multirow{3}{*}{$\begin{array}{l}\text { Scaleofself-interest (6): } \\
\text { Шкала самоінтересу (6): }\end{array}$} & Experimental/ Експериментальна & 35 & 38.53 & 1348.50 \\
\hline & Control/ Контрольна & 35 & 32.47 & 1136.50 \\
\hline & Total/ Всього & 70 & & \\
\hline \multirow{3}{*}{$\begin{array}{l}\text { Scaleofself-understanding (7): } \\
\text { Шкала саморозуміння(7): }\end{array}$} & Experimental/ Експериментальна & 35 & 37.27 & 1304.50 \\
\hline & Control/ Контрольна & 35 & 33.73 & 1180.50 \\
\hline & Total/ Всього & 70 & & \\
\hline
\end{tabular}




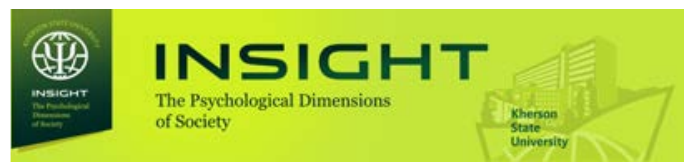

Kokorina Yuliia,

Psatii Alla

Table 6. Statistical significance of the peculiarities of the self-esteem functions in the experimental and control groups Таблиця 6. Статистична значущість особливостей самоставлення в експериментальній та контрольній групах

\begin{tabular}{|c|c|c|c|c|c|c|c|c|c|c|c|c|}
\hline \multicolumn{13}{|c|}{ Test statistics/ Статистики критеріїв } \\
\hline &  & 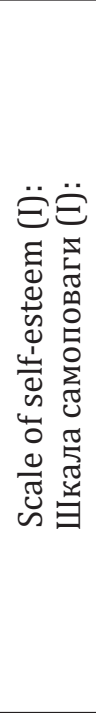 &  & 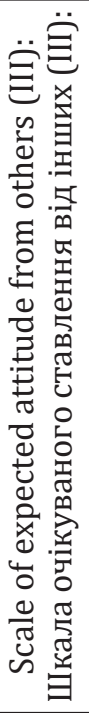 & 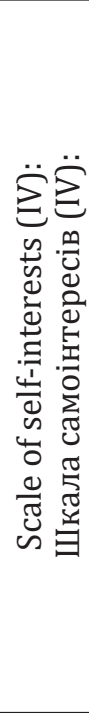 & 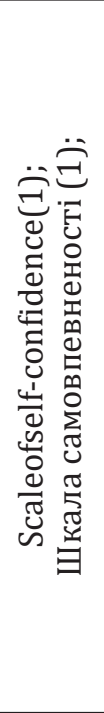 & 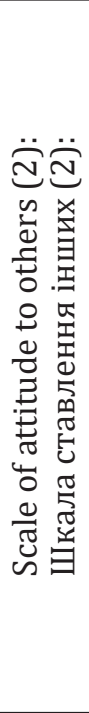 &  & 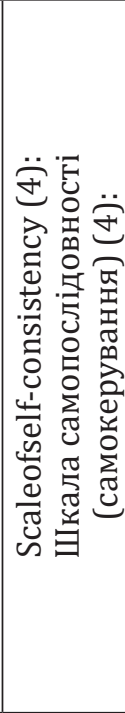 & 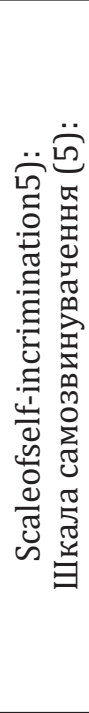 & 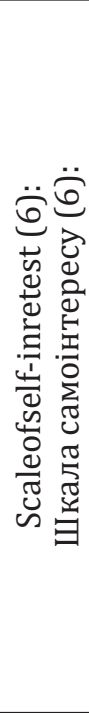 & 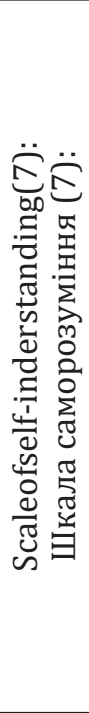 \\
\hline 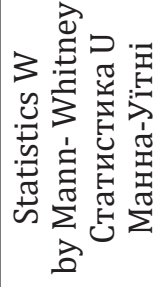 & $\begin{array}{l}\stackrel{8}{0} \\
\stackrel{1}{\text { N }}\end{array}$ & $\begin{array}{l}8 \\
\text { Ln } \\
\infty \\
\text { N } \\
i n\end{array}$ & 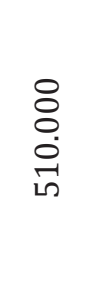 & $\begin{array}{l}8 \\
\vdots \\
\infty \\
\infty \\
\text { ஸे }\end{array}$ & 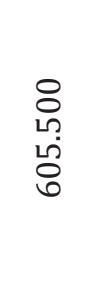 & $\begin{array}{l}\text { \& } \\
\text { Ln } \\
\text { Ñ } \\
\text { గn }\end{array}$ & $\begin{array}{l}8 \\
\text { Ln } \\
\hat{N} \\
\text { in }\end{array}$ & $\begin{array}{l}\stackrel{8}{0} \\
\stackrel{0}{ } \\
\infty \\
\ddot{\sigma}\end{array}$ & $\begin{array}{l}8 \\
\text { in } \\
\text { ర̊ } \\
\text { Ln }\end{array}$ & 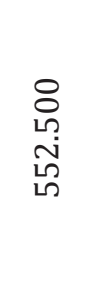 &  & $\begin{array}{l}8 \\
\text { นn } \\
\text { ํ. } \\
\text { hn }\end{array}$ \\
\hline 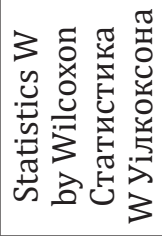 & $\begin{array}{l}8 \\
8 \\
\stackrel{0}{0} \\
\text { 능 }\end{array}$ & 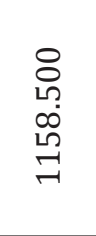 & $\begin{array}{l}\stackrel{8}{8} \\
\stackrel{0}{+} \\
\stackrel{+}{+} \\
\overrightarrow{7}\end{array}$ &  & 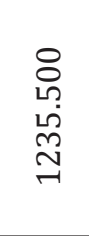 & 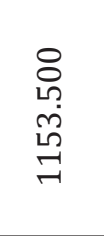 & 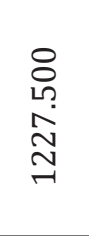 & $\begin{array}{l}\stackrel{8}{0} \\
\circ \\
\infty \\
0 \\
\circ \\
\ddots\end{array}$ & 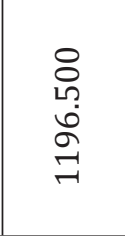 & 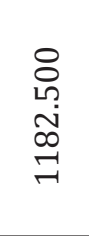 & 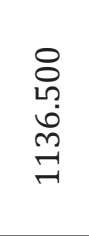 & 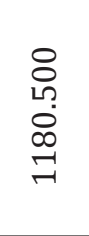 \\
\hline$N$ & $\begin{array}{l}\stackrel{0}{\infty} \\
\stackrel{\sim}{-1} \\
\underset{1}{1}\end{array}$ & $\begin{array}{l}\text { L } \\
\text { के }\end{array}$ & $\underset{\stackrel{m}{7}}{\stackrel{\sim}{\sim}}$ & $\begin{array}{l}\text { שֶ } \\
\stackrel{0}{i}\end{array}$ & $\begin{array}{l}\text { m } \\
0 \\
0 \\
i\end{array}$ & $\begin{array}{l}\text { 오 } \\
\text { ํ. } \\
\text { i }\end{array}$ & $\stackrel{\infty}{\stackrel{\infty}{\rightarrow}}$ & 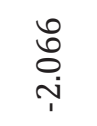 & $\begin{array}{l}0 \\
\stackrel{1}{1}\end{array}$ & $\begin{array}{l}\infty \\
\stackrel{2}{i}\end{array}$ & $\stackrel{\substack{\stackrel{\leftrightarrow}{N} \\
\rightarrow}}{\rightarrow}$ & $\stackrel{\infty}{\stackrel{\infty}{\stackrel{p}{i}}}$ \\
\hline 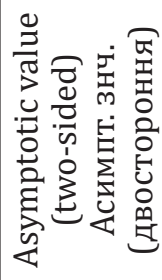 & :ิ & $\stackrel{\text { }}{\text { ๗ి }}$ & $\stackrel{\stackrel{\sim}{N}}{\sim}$ & $\stackrel{\mathscr{L}}{+}$ & m. & ঐิ & 虽 & ตे. & 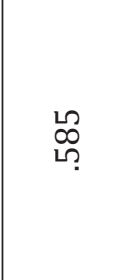 & 疍 & $\begin{array}{l}\infty \\
\stackrel{丶}{\sim}\end{array}$ & ô \\
\hline
\end{tabular}

Note: The load of significant variables is highlighted in bold.

Примітка: Навантаження значущих змінних виділено жирним шрифтом.

that are expressed through emotional and external types of behaviour and a decrease in the value for the restrictive type. On the one hand, through
Попри схожість отриманих результатів,було також перевірено статистичну значимість відмінностей між результатами дослідження самоставлення у контрольній 
the actualization of these strategies, we can see the actualization of cultural (external type) stereotypes regarding food and a coping strategy with negative/anxiety experiences (emotional type).On the other hand, food becomes an object to which the relationship with the significant other is projected unconsciously, allowing us to respond to conflict/traumatic situations. As a result, food becomes a form that is filled with anxiety and desires.

The respondents in the control group obtained the low rates of all eating behaviours and it is not typical for them to shift the psycho-emotional tension and react with eating behaviours.

The study of personality self-esteem was connected to the assumption that the type of eating behaviour is directly related to and reflects the formation and balance of the self-concept components.

In the study of self-esteem, it can beseen that the experimental group obtained average rates on most scales (from 50 to 74 ), in contrast to the control group, where the rates on most scales decreased (from 30 to 60).

Therefore, for respondents in the experimental group with average scores on scale $\mathrm{S}$ "global selfconcept" (58.10), there is a decrease in rates on scale II "auto-sympathy" (47.89) and on scale III "expectation of attitude from others" (36.59). Such values may indicate an internal undifferentiated conflicting sense of oneself, where the core is a lack of positive self-acceptance and a projectionofthe expectations of disapproval and misunderstanding with the others. Relatively high rates are on scale IV "self-interest" (67.13), average scores are on the "self-consistency" scale (58.64) and low rates on the scales: "self-confidence" (47.45), "attitude of others" (34.09), "self-understanding" (45.94).The rates reveal the peculiarities of the respondents' attitude towards themselves, which depends on the degree of adaptation to various situations and allow to speak about a certain rigidity of selfconcept, the desire to keep the image of oneself intact, focus on himself, on the feelings, thoughts, and desire to be interesting for others. However, та експериментальній групах за допомогою непараметричного критерію Манна-Уітні (табл. 5).

Отже, як можна побачити у наведеній вище таблиці, середні ранги та їхні суми в експериментальній і контрольній групах мають різні значення.

Далі було проаналізовано статистичну значущість цих відмінностей (табл. 6).

Як можна побачити з наведеної таблиці, експериментальна та контрольна групи відрізняються між собою за інтегральною шкалою S “глобальне самоставлення" - контрольна група має більш позитивні характеристики самоставлення (ps.029), та за шкалою 3 (“самоприйняття") із рівнем статистичної значимості $(\mathrm{p} \leq .039)$.

\section{Дискусія}

Отримані результати відкривають поле для подальшої дискусії. Методологічною рамкою даного дослідження $є$ положення системно-структурного та психодинамічного підходів. Структура самоставлення респондентів у двох групах в залежності від типу харчової поведінки поряд зі схожістю має деякі особливості.

Отже, якщо звернути увагу на дані показників типу харчової поведінки у респондентів експериментальної групи, то можна побачити напругу за двома типами: емоційним та екстернальним. А для респондентів контрольної групи характерно зниження показників за усіма типами харчової поведінки. Тобто, для особистості, у якої спостерігається порушення харчової поведінки, можна побачити основні стратегії, які виражаються через емоційний та екстернальний (зовнішній) тип поведінки, та зниження показника за обмежувальним типом. 3 одного боку, через актуалізацію даних стратегій можна побачити актуалізацію культуральних (екстернальний тип) стереотипів щодо їжі та стратегію подолання 3 негативними/тривожними переживаннями (емоційний тип). 3 другого боку, їжа стає тим об'єктом, на який несвідомо проектуються стосунки зі значущими іншим, що дозволяє відреагувати конфліктні/травматичні ситуації. Тобто, їжа стає тою формою, яку наповнюють тривоги і бажання.

Щодо низьких показників за всіма типами харчової поведінки для респондентів контрольної групи, то, ймовірно, для них не 
the loss of a sense of the power of oneself, the questioning of one's dignity and worth to the other, the disapproval of own intentions and actions lead to increased anxiety, transferring anxiety and worry into eating behaviour. In other words, a new situation can cause anxiety, tension, which leads to an increased willingness to submit to environmental influences, which is associated with a weakening of the self-regulatory capacities of the individual and can be expressed through disorder of eating behaviour. These findings correlate with researchesofmodern scientists who have emphasized: lack of self-identity in eating addicts, underestimation of one's own value, feelings of guilt, low levels of self-understanding, rigidity and feelings of social deficit (Kovalchuk, 2019, Lymar, 2018, Isaksson, 2021).

This strategy can be analysed in terms of a psychodynamic approach: food is detached from its functional purpose and begins to fulfil a complex role - the role of internal objects, which form the psychic of personality, can be depleted because they are not sufficiently formed. A person, facing his own weakness, cannot resist the anxiety. And the only way to cope with it is to displace it with a relationship with food, as the last unconsciously reflects a significant other with whom the relationship is restored.

Compared to the experimentalgroup, the control group showed a decrease (from 36 to 45 ) in the integral value of self-esteem, whose structural components were the scales: "self-esteem", "autosympathy", and "expectation of attitude from others". The average rates on the scales: "selfconsistency" (54.32), "self-interest" (57.46), "selfincrimination" (59.32), high rates on the "selfinterest" scale (65.52).These data may indicate a relative flexibility of the self-concept, formed respondents' perception of their own activity and responsibility for it, the perception of their own value and the value of their inner world, and at the same time, an internal willingness to be selective about their own, a tendency to accept not all their advantages and criticize not all their failures (lower scores on the S scale). It
$€$ характерним зсув психоемоційної напруги і реагування через харчову поведінку.

Дослідження особливостей самоставлення особистості було пов'язане з припущенням, що тип харчової поведінки відображає сформованість та збалансованість компонентів Я-концепції.

Стосовно вивчення самоставлення, то можна побачити, що в експериментальній групі отримані середні показники по більшості шкал (від 50 до 74), на відміну від контрольної групи, де показники за більшістю шкал зниженні (від 30 до 60).

Отже, для респондентів експериментальної групи при середніх показниках за шкалою S “глобальне самоставлення" (58.10) спостерігається зниження показників за шкалою II “аутосимпатія" (47.89) та за шкалою III "очікування ставлення від інших" (36.59). Такі данні можуть свідчити про внутрішнє недиференційоване суперечливе почуття самого себе, де ядром стає дефіцит позитивного сприйняття себе і проекція очікування несхвалення, нерозуміння з боку інших людей. Відносно високі показники за шкалою IV "самоінтерес" (67.13), середні показники за шкалою “самокерування" (58.64) та низькі показники за шкалами: “самовпевненість" (47.45), “ставлення інших" (34.09), “саморозуміння" (45.94) розкривають особливості ставлення респондента до свого “Я”, що залежить від ступеня адаптації до різних ситуацій, а також дозволяють говорити про певну ригідність Я-концепції, прагнення зберегти у незмінному вигляді образ самого себе, зосередженість на собі, на власних почуттях, думках, бажанню бути цікавим для інших. Однак втрата відчуття сили свого Я, сумнів у своїй гідності та цінності для іншого, несхвалення своїх намірів та дій призводять до посилення тривоги, переносячи тривогу та занепокоєння у бік харчової поведінки. Інакше кажучи, нова ситуація може викликати тривогу, напругу, що призводить до посилення схильності підкорятися впливу навколишнього середовища, що пов'язано 3 ослабленням регуляційних можливостей “Я” людини, та може виражатися через порушення харчової поведінки. Данні висновки корелюють з дослідженнями сучасних науковців, які акцентували увагу на: відсутності у харчових адиктів самоідентифікації, недооцінювання власного “Я", почутті провини, низького рівню саморозуміння, ригідності 
can be assumed that due to a relatively balanced/ stable view of themself (all scales have no spikes), a person has more balanced eating behaviour because there is no transfer of psycho-emotional conflict to food.

\section{Conclusions}

The conducted empirical study of the types of eating behaviour as a form of personality self-esteem revealed that the experimental and control groups differ from each other in all types of eating behaviour: restrictive, emotional, and external. In a comparative analysis of the obtained data of the experimental and control groups, an eating behaviour of the respondents in the experimental group differs with greater tension in all types than the respondents in the control group with a high level of statistical significance ( $p \leq .001)$.

During the analysis of personality self-esteem features, it was found that the experimental and control groups differed on the S scale "global self-esteem" ( $\mathrm{p} \leq .029)$ and on the 3 scale "selfacceptance" ( $\mathrm{p} \leq .039)$ - the control group has more positive characteristics of self-esteem.

Therefore, the study revealed that the type of eating behaviour becomes the measurement and form, by which a person historizes himself, forms a personal vector of attitude towards himself, creating a single frame of constitution of himself, in which the image of food has an order either imaginary or symbolic, framing the type of relationship with it. It should also be noted that the results obtained in this study may be further clarify and comprehend the formation of personal identity, the derivative of which is self-attitude, and how its formation affects the type of eating behaviour. The results can be considered and implemented in psychocorrective and psychoprophylactic programmes for the individual as part of dealing with eating disorders.

\section{References}

Absalamova, L. N. (2017). Quality of life and eating behaviour in neurotic patients. Psychology: reality and prospects, 9, 12-18. та почутті соціального дефіциту (Ковальчук, 2019, Лимар, 2018, Isaksson, 2021).

Дана стратегія може бути розглянута 3 точки зору психодинамічного підходу: їжа відокремлюється від свого функціонального призначення і починає виконувати складну роль - роль внутрішніх об'єктів, які формують психічну складову особистості, можуть виснажуватися, оскільки не є в достатній мірі сформованими, призводячи до того, що людина, зіштовхнувшись зі своєю слабкістю, недостатністю, переживає тривогу, яку неможливо витримати. I єдиним способом впоратися 3 нею - відвести, змістити її через ставлення до їжі, оскільки остання несвідомо відображає значущого іншого, з яким відбудовуються взаємини.

У порівнянні з експериментальною групою, в контрольній групі по інтегральному показнику самоставлення, структурними компонентами якого є шкали: “самоповаги”, "аутосимпатії, “очікування ставлення від інших",спостерігається зниження даних (від 36 до 45). Середні показники за шкалами: “самопослідовність" (54.32), “самоінтерес" (57.46), “самозвинувачення" (59.32), високі показники за шкалою "самоінтересів" (65.52). Отримані данні можуть свідчити про відносну гнучкість Я-концепції, сформованість у респондентів уявлення про власну активність та відповідальність за неї, спостерігається вираженість сприйняття власної цінності та цінності свого внутрішнього світу, i, водночас, виражена внутрішня готовність до вибіркового ставлення до себе, схильність приймати не всі свої переваги і критикувати не всі свої недоліки (зниження показників по шкалі S). Можна припустити, що завдяки відносно збалансованому/стабільному погляду на себе (всі шкали не мають піків), у особистості спостерігається більш збалансована харчова поведінка, оскільки на їжу не відбувається перенесення психоемоційного конфлікту.

\section{Висновки.}

У ході проведеного емпіричного дослідження типів харчової поведінки як форми самоставлення особистості було встановлено, що експериментальна та контрольна групи відрізняються між собою усіма типами харчової поведінки: обмежувальним, емоційним та екстернальним. При порівняльному аналізі отриманих даних експериментальної 
Bezsteiko, V. (2018). Recommendations for the management of eating disorders, NEURO NEWS, 4-5 (97), 6-7.

Kovalchuk, Z. Y. (2019). Psychological aspects of eating disorders among women. Insight: Psychological dimensions of society, 2, 91-98.

Litvin-Kindratyuk, S. D. (2000). Eating activity of the individual: traditional and innovative strategies. Collection of scientific works: philosophy, sociology, psychology, 5 (1), 160-165.

Malkina-Pykh, I. G. (2007). Eating behaviour therapy. Moscow: Eksmo.

Moizrist, A. N. (2009). Types of eating disorders (a theoretical analysis in the literature). Problems of modern psychology, 6 (2), 85-94.

Stolin, V. V. Bodalev, A. A. \& Avanesov, V. S. (2006). General psychodiagnostics. SPb.: Publishing house "Rech".

Shebanova, V. I. (2014). Eating habits of a person, food, body as a phenomenon of everyday reality. Problems of modern psychology, 24 (2), 717-730.

Butler, R. J. \& Gasson, S. L. (2006). Development of the Self-image profile for adults. European Journal of Psychological Assessment, 22 (1), 52-58.

Isaksson, M., Ghaderi, A., Wolf-Arehult, M., et al. (2021). Overcontrolled, undercontrolled, and resilient personality styles among patients with eating disorders. Eating Disorders, 9, 47, Retrieved from https://doi.org/10.1186/ s40337-021-00400-0

Kornacka, M., Czepczor-Bernat K., Napieralski, P., et al. (2021). Rumination, mood, and maladaptive eating behaviours in overweight and healthy populations. Eating and Weight Disorders - Studies on Anorexia, Bulimia and Obesity, 26, 273-285. Retrieved from /https://doi.org/10.1007/s40519-02000857-z

Lindvall Dahlgren, C. \& Rø, Ø. (2014). A systematic review of cognitive remediation therapy for anorexia nervosa - development, current state and implications for future research and clinical practice. Eating Disorders, 2, 26. Retrieved from / https://doi.org/10.1186/s40337-014-0026-y

Tchanturia, K., Lloyd, S. \& Kang, K. (2013). Cognitive remediation therapy for anorexia nervosa: current evidence and future research direction. Eating Disorders, 46(5). P.492-495. Retrieved from / https:// doi.org/10.1002/eat.22106

Rymarczyk, K. (2021). The role of personality traits, sociocultural factors, and body dissatisfaction in anorexia readiness syndrome in women. Eating Disorders, 9, 51, Retrieved from / https://doi. org/10.1186/s40337-021-00407-7 і контрольної груп, харчова поведінка для респондентів експериментальної групи відрізняється більшою напругою по всіх типах, ніж для респондентів контрольної групи 3 високим рівнем статистичної значущості (ps.001).

У ході якісного аналізу особливостей самоставлення особистості було встановлено, що експериментальна та контрольна група відрізняються між собою за шкалою S “глобальне самоставлення" $(\mathrm{p} \leq .029)$ та за шкалою 3 “самоприйняття” (p $\leq .039)$ - контрольна група має більш позитивні характеристики самоставлення.

Таким чином, дослідження показало, що тип харчової поведінки стає виміром та формою, через яку людина історизує себе, формує особистісний вектор самоставлення, створюючи єдину рамку конституювання себе, у якому образ їжі носить порядок, або уявний, або символічний, оформлює тим самим тип відносин з нею. Також слід зазначити, що, отримані у ході дослідження результати, можуть у подальшому краще висвітлити і зрозуміти формування ідентичності особистості, дериватом якої є самоставлення, і те, як її сформованість впливає на тип харчової поведінки. Все це може бути враховано і впроваджено у складанні психокорекційних і психопрофілактичних програм особистості в рамках роботи з порушенням харчової поведінки.

\section{Список використаних джерел}

Абсалямова Л. Н. Якість життя та харчова поведінка невротично хворих людей. Психологія: реальність і перспективи. 2017. № 9, C. 12-18.

Безштейко В. Рекомендації щодо менеджменту розладів харчової поведінки, HEЙРО NEWS. № 4-5 (97). 2018, С. 6-7.

Ковальчук 3. Я. Психологічні аспекти порушення харчової поведінки ужінок. Інсайт:Психологічні виміри суспільства. 2019. № 2, С. 91-98.

Литвин-Кіндратюк С. Д. Харчова активність особистості: традиційні й інноваційні стратегії. Збірник наукових праць: філософія, соціологія, психологія. Івано-Франківськ: Вид-во “Плай" Прикарпатського ун-ту, 2000.№ 5. Ч. 1., С. 160-165.

Малкина-Пых И. Г. Терапия пищевого поведения. М.: Эксмо, 2007, С. 617-639.

Мойзріст О. М. Види порушень харчової поведінки (теоретичний аналіз літературних джерел). Проблеми сучасної психології. Інституту 
Van Strien, T. \& Ouwens, M. A. (2007). Effects of distress, alexithymia, and impulsivity on eating. Eating Behaviors, (8), 251-257. Retrieved from / https://doi.org/10.1016/j.eatbeh.2006.06.00 психології ім. Г.С. Костюка АПН України. 2009. № 6. Ч. 2, С. 85-94.

Столин В.В. Бодалев А.А. Аванесов В.С. Общая психодиагностика. СПб.: Изд-во “Речь”, 2006. $440 \mathrm{c.}$

Шебанова B.I. Харчова поведінка людини, їжа, тілесність як феномени повсякденної реальності. Проблеми сучасної психології. 2014. Т. 2, Випуск 24., С. 717-730.

Butler, R.J., Gasson, S.L. Development of the Self-image profile for adults. European Journal of Psychological Assessment, 2006. 22 (1), 52-58.

Isaksson, M., Ghaderi, A., Wolf-Arehult, M.et al. Overcontrolled, undercontrolled, and resilient personality styles among patients with eating disorders.Eating Disorders, 2021, 9,47,Retrieved fromhttps://doi. org/10.1186/s40337-021-00400-0

Kornacka, M., Czepczor-Bernat, K., Napieralski, P.et al. Rumination, mood, and maladaptive eating behaviors in overweight and healthy populations. Eatingand Weight Disorders-Studies on Anorexia, Bulimia and Obesity, 2021,26,273-285. Retrieved from /https://doi.org/10.1007/s40519-02000857-z

Lind vall Dahlgren, C., Rø, Ø. A systematic review of cognitive remediation therapy for anorexia nervosa development, current state and implications for future research and clinical practice. Eating Disorders, 2014,2,26. Retrieved from / https://doi. org/10.1186/s40337-014-0026-y

Tchanturia, K., Lloyd, S., Kang, K. Cognitive remediation therapy for anorexia nervosa: current evidence and future research direction. Eating Disorders, 2013, 46(5). P. 492-495. Retrieved from /https:// doi.org/10.1002/eat.22106

Rymarczyk, K. The role of personality traits, sociocultural factors, and body dissatisfaction in anorexia readiness syndrome in women. Eating Disorders, 2021, 9, 51, Retrieved from / https://doi. org/10.1186/s40337-021-00407-7

VanStrien T, Ouwens M.A. Effects of distress, alexithymia and impulsivity on eating. Eating Behaviors, 2007, (8), 251-257. Retrieved from / https://doi. org/10.1016/j.eatbeh.2006.06.004 